\title{
DESIGNING EVE (ENGLISH VOCABULARY EXERCISES) BY USING HOT POTATOES AS SUPPLEMENTARY MATERIAL FOR TEACHING VOCABULARY TO ELEMENTARY LEVEL STUDENTS
}

\author{
By: \\ Ahmad Lukmanul Hakim \\ English Study Program FKIP Universitas Tanjungpura Pontianak \\ ahmddlukman@gmail.com
}

\begin{abstract}
This research was conducted in order to create EVE, an electronic game that can be used to teach and learn vocabularies. The objectives of this research is to see whether EVE can be used to teach vocabulary to elementary school students as a supplementary teaching media. This research takes the form of developmental research. This developmental research was performed in order to create new teaching materials. The research method consists of four phases: analyzing, designing, developing, and implementing also known as ADDI method. Several vocabulary materials from different books and sources were combined with the Hot Potatoes application for teaching vocabularies to complete the designed product. The EVE was created for approximately 50 minutes in teaching and learning period. The completed research was implemented with 11 elementary students from different schools. To sum it up, the researcher found that EVE is usable for teaching vocabulary to elementary level students especially in gaining students' interest and motivate students to learn vocabulary in more pleasing way.
\end{abstract}

Keywords: a development research, English vocabulary exercises, supplementary material, vocabulary

\section{INTRODUCTION}

Vocabulary is one of the most important aspects of English teaching

and learning. Vocabulary can be defined as a core element of language use, and research exploring its relationships with other components of linguistic competence constitutes an important subfield of applied linguistics (Szudarski, 2018). It is 
indicated that vocabulary plays an important role in learning English. Thus, the teachers were expected to give more space for the students in learning more vocabulary effectively.

The teacher can utilize technology to help students learn languages by facilitating and mediating their learning. In current era, especially in educational technology, teaching English through multimedia is a popular subject. One of many ideas is teaching vocabulary by using multimedia.

Based on the researcher's observation, when the teacher used multimedia in the teaching and learning process, the students were more interested in learning, according to the teacher. Multimedia may help the teacher in presenting information in a way that the students can understand (Leow \& Neo, 2014).
According to the preobservational research that has been conducted on SDN Muhammadiyah 2 Pontianak, the researcher found that the vocabulary teaching in the school was boring and the students did not look motivated enough in following the class material, the class still used the conventional media in teaching vocabulary to the students. The students only learned in the class with the teacher and the books, it might be possible that the books that they used were too expensive to afford so that the learning was not that motivating for both the educators, the students as well as the parents.

Based on several similar research about designing supplementary material for teaching vocabulary for the students conducted by Puspita et al. (2017) showed that their supplementary material still uses 
written text eventhough their students at elementary school in supplementary material contained memorizing vocabularies.

images, researcher found out that it has slight differences with old ways of teaching. Syamsudin and Kurniawati (2016) also found that the students will enjoy taking the test if the material is made out of hot potatoes. They will approach learning English with enthusiasm because it will be a new challenge and experience for them. Based on those problems, the researcher decided to fulfill the gaps between the old teaching ways by creating EVE.

The English Vocabulary Exercises (henceforth, EVE) is an electronic game that contain several games such as fill in the blank game, multiple answer, quiz and crossword puzzle with interesting and colourful pictures. EVE as supplementary materials help to encourage the
EVE is an electronic game that helps student learns vocabulary. It was designed to help facilitate the teaching and learning process for students at the elementary level.

The advantages of using this product are that it is free to download and suitable for this era that use technology in teaching. EVE is a product as a whole where the product has an advantage for teachers and parents where they can get instructions on how to make games like the one there and the advantage for students, they can download and access an application that has several games in it.

EVE created using software called Hot Potatoes. Not many people know about this application, because it's still uses the old way for 
programming. Hot Potatoes is a useful tool for creating many games for entertaining, which often include a variety of games such as crossword puzzle, fill in the blank, quiz and also include effects such as animation, sound, and clip art. EVE can be used by old laptop or the newest laptop system.

Hot Potatoes consists of six programs that can be used to create interactive and web-based teaching materials and questions (Amir, Siswaningsih, and Hana, 2013). There are some advantages of using the Hot Potatoes application as stated by (Khikmawati, 2014). Those are:

1. More efficient in terms of energy and time.

2. Cost efficient because it is not necessary to print questions if an evaluation of learning outcomes is carried out so that printing costs can be allocated to other learning activities.

3. The questions done between one student and another have a different arrangement, because the questions are usually randomized by the test maker.

4. For multiple choice questions, right and wrong can be directly assessed by software.

The researcher provided insights about why EVE is needed in this study to act as a supplementary teaching media. In addition, in this analysis, the supplementary media means a media or content that allows educators to support teaching English in a classroom when faced with inadequate techniques and methods (Reddy, 2014). In addition, Sutini, Emzir and Rasyid, 2021) mentioned that print media, such as books, and electronic media, such as Computer 
Based Training (CBT), Web Based

Training

(WBT)

Internet

(Interconnection Networking), are examples of teaching materials.

The use of a computer to present text, graphics, video, animation, and sound in an integrative way is multimedia. According to Pun (2013) (2013) Multimedia is defined as interactive computer-based programs that use both hardware and software to allow users to share their thoughts and data. Text, images, sound, video, and animation are all used. EVE as multimedia in teaching and learning activities has several elements that have been listed above such as a combination of text and graphics. Other elements such as sound, video and animation will likely be added due to the limited time of the researcher.
The researcher hoped that EVE would become one of many supplementary teaching materials that could help the teaching and learning process. Kiat et al (2020) found that through learning with the integration of multimedia-mediated content, student achievement is enhanced, and it has helped students to develop a better understanding. There are some of the essential advantages of using multimedia technology (Pun, 2013). Multimedia encouraged students to learn English, improved the communication skills of students, widened the knowledge of students about the English culture, improved teaching efficiency, increased interaction between students and between teachers and students, created a pleasant teaching atmosphere in the classrooms and provided opportunities outside the 
classroom for English teaching. ADDIE concept in this study to create Multimedia can also encourage an electronic game to teach students to learn English, based on vocabulary.

the above advantages, and it can develop a decent teacher and student atmosphere in the teaching and learning process.

The topic of this study was "Designing EVE by using Hot Potatoes Application as Supplementary Material for Teaching Vocabulary to Elementary Level Students".

\section{METHODOLOGY}

The researcher used developmental research on the basis of the research problem above. The aim of research in development was to develop new or enhanced interventions or methods to achieve a well-defined purpose or goal of learning. The researcher used the

\section{vocabulary.}

An instructional design used by the researcher; the ADDIE approach. There are five stages of developmental research, according to (Forest, 2017). Analyze, design, develop, implement and evaluate (ADDIE). This method had been successfully applied to the development of educational products and other learning resources.

However, due to the study's limited time, the researcher appeared to focus just on four phases: analyze, design, develop, and implement (ADDI). There was certainly a possibility for the researcher to extend the evaluation to the classroom. To clarify what needed to be done at every stages. There are some points that had been done in this 
research. The following points that had been done were:
1)Analyzing
2)Designing

3)Developing 4)Implementing. The informants for this study were the English teacher of elementary school who taught the elementary grade students as the informant and respondent in the interview to find out the current teaching and learning issues as well as the students' need or difficulties in learning vocabularies.

Moreover, the research was conducted at the students' house because the regulation of the government about COVID-19 virus. This study focused on identifying the students' needs in learning vocabulary.

In order to complete the EVE's final product, the researcher collected data from the informant. It is important to use the data from this study to find EVE as a supplementary teaching material to teach vocabulary. In addition, the data from this study could be used in the validation stage for further analysis to test EVE as a supplementary Teaching material to understand the consistency of the product. Latterly the teacher and the students also acted as the object of the product.

The researcher conducted an interview with the English teacher in order to obtain information on the needs of elementary school students and the problems (the skill of the students, motivation, etc.). The researcher asked detailed questions related to the method of teaching and learning. The researcher conducted a semi-structured interview in which the interviewer was asked the proper order of questions that the researcher had agreed in advance. The research 
believed that the use of a good interviewed the students on a limited sequence of questions that had been number of subjects. Those are related prepared before would allow the to this research. The researcher has researcher to have an interview with found that when learning vocabulary, more focus. the learners were not enthusiastic.

The researcher took advantage of The researcher had found that when the unstructured interview. The studying vocabulary, the students unstructured interview was chosen weren't enthusiastic. The researcher because the researcher wanted to find was asked the question using the the particular subject, but had no manpower question guide for framework or schedule or expectation interviews with the students.

as to how the respondents proceed, Then the researcher also did the and the specific topic in this research was to find out about the problems of learning vocabulary for students. collect materials or data from They were defined by Zhang and different sources to help the product's Wildemuth (2009) as interviews in which neither the question nor the response categories are predetermined.

Instead, they depended on the researcher and the informant to have social contact. The investigator design process. The information from the interview, instructional material from books or textbooks and so on were the sources here.

The researcher analyzes the interview through the use of thematic analysis in data analysis. In 
qualitative research, it is a widely used technique. The data may consist of transcripts of the interviewers' interviews. A method used to identify, analyze, and report patterns (themes) within the data is thematic analysis (Braun and Clarke, 2006).

The methods used for the research largely followed the Braun and Clarke (2006) approach proposed. First, the researcher will transcribe and interpret the interviews and make valuable notes on the interview data and become familiar with the data. Second, auto recordings and transcripts. By using colored pens and notes, the researcher can code the interview data manually. By using colored pens and notes, the researcher can code the interview data manually. Third, the researcher selects the interview data by looking for the themes, the researcher focuses on the border level of themes and sorting the various codes. Fourth, themes for review. Fifth, themes for defining and naming. Sixth, the researcher will write the report based on the data examined in the analysis of the report. After completing all the procedures, the researcher obtained a list of the important points that can be used to design "EVE". Then, the content analysis was translated into descriptive data or text. In particular, the data is collected from the evaluation rubric for teachers and students. The researcher was using the results of the assessment rubric to determine the pattern of the informants' feedback, and below are the three measurement points used to determine if the study participants agreed with the statements made. 


\begin{tabular}{|c|c|}
\hline $\begin{array}{l}\text { Point of } \\
\text { measurement }\end{array}$ & Agreement level \\
\hline 3 & $\begin{array}{c}\text { Very } \\
\text { Satisfed }\end{array}$ \\
\hline 2 & $\begin{array}{c}\text { Well } \\
\text { Enough }\end{array}$ \\
\hline 1 & Unsatisfied \\
\hline
\end{tabular}

(Taken from Andina 2016)

After that, the data above was being measured by the formula as follows:

\section{Total Score}

$$
\mathrm{P}=\text { Amount of Point } x
$$

Amount of categories $x 100$

Where $\mathrm{P}:$ the percentage of the Experts' Recommendation

(Adapted from Ary et al., 2010)

The feedback tendency of the informant was calculated using the formula above. The final product was created according to Andina (2016) table to achieve the final percentage after obtaining the outcome of the tendency point from the validators in the assessment rubric.
After the usability of the final product was determined, the researcher described the findings in descriptive information. The researcher would make the final revision of the product if necessary, provided that the experts want the researcher to enhance the designed teaching material.

\section{RESULT AND DISCUSSION}

The researcher describes each phase of the chosen ADDIE model in this chapter to answers the research questions. Specifically, the four ADDI phases of this development research are explained in this section. The purpose of this study was to develop games for elementary-level students in Pontianak to teach vocabulary. The product that is EVE can be accessed from this link: 
evasupplementarymaterial.blogspot.c

om

\section{Analyzing Phase}

The researcher conducted an interview with the English teacher in order to collect information regarding the needs of elementary level students in learning vocabulary. The data was gathered through the English teacher's interview. On October 17, 2019, an interview was conducted with English teacher in SDN Muhammadiyah 2 Pontianak, who taught elementary level students. During this process, the researcher performed an unstructured interview in which the respondent was asked a good series of questions that the researcher had prepared ahead of time (Cohen et al., 2018).

\section{Designing Phase}

This product was developed by the researcher to fulfill the vocabulary

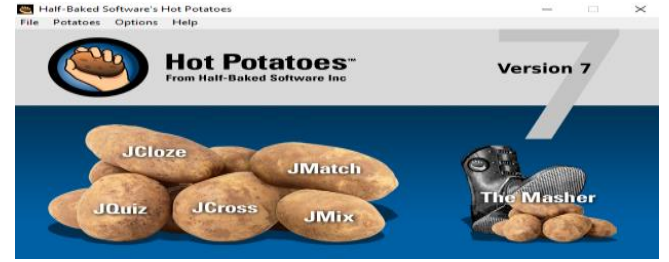

needs of elementary level students in the teaching and learning process. EVE can be used flexibly in the teaching learning process as a supplementary teaching media, depending on the needs of the teacher and students. However, during the teaching and learning process, the material of the EVE should be introduced strategically (Branch, 2009).

\section{Developing Phase}

During this phase, the researcher began developing the product using the software chosen based on the results of the previous phase's survey. 
Hot Potatoes is the program used by the researcher at this phase. Hot potatoes provided several games to make, the researcher, teachers, parents can decide which games they wanted to make. See the picture below.

\section{Picture 1. Hot Potatoes Home}

\section{Interface}

Here are some features of Hot Potatoes:

1. Jcloze

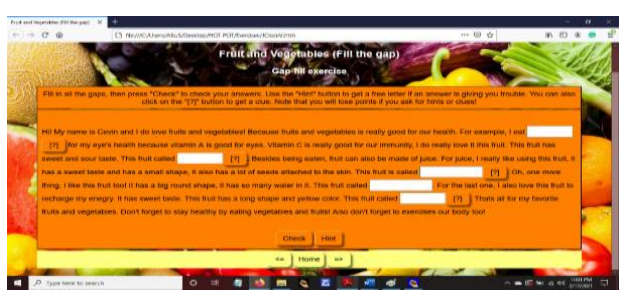

2. JMatch

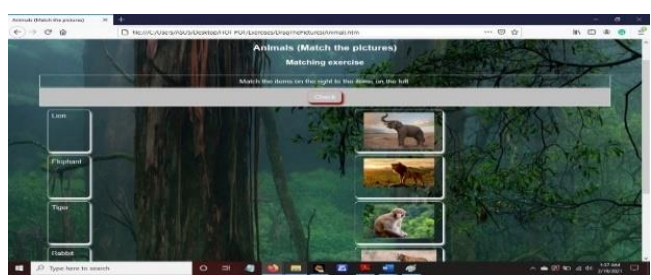

3. JQuiz

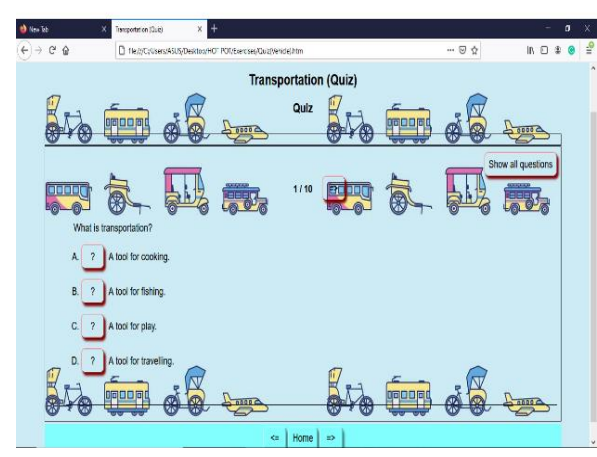

4. JCross

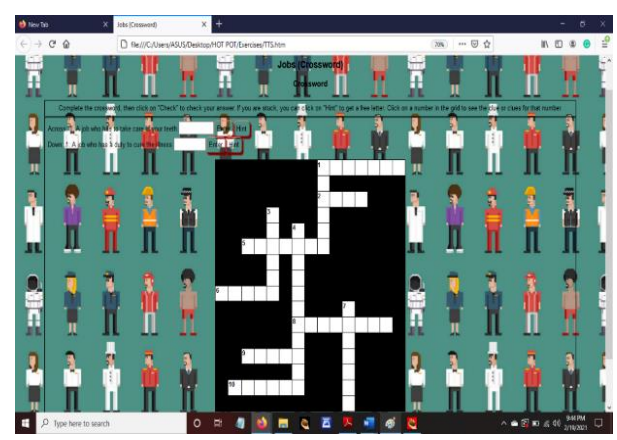

5. The Masher

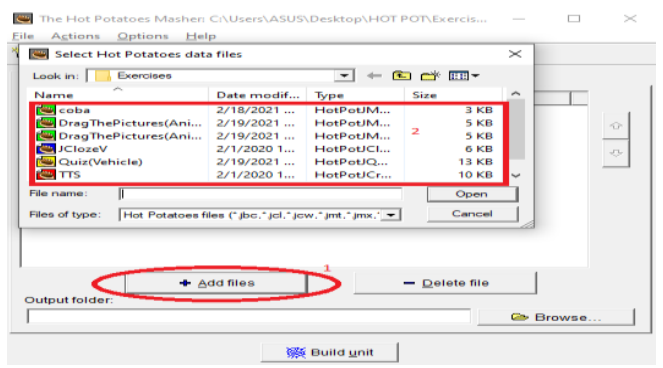

Finished Product

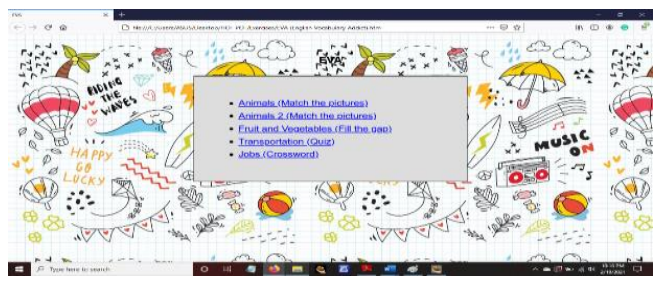


Teachers' responsibility in the teaching and learning process has become encouraging elementary school students to learn vocabulary by utilizing appropriate teaching resources. Unfortunately, according to the researcher's interview with the English teacher during the analyzing phase, there were several issues in the classroom during the teaching process. The students' interest in learning was very low, and their desire to learn was considered low. As a result, the ability of elementary school students, especially in terms of learning vocabulary, was still below average. He went on to say that encouraging them to be more interested in learning vocabularies was difficult for her. Furthermore, the teacher's teaching tools were insufficient to support the teaching process and encourage students to learn. Multimedia that integrates pictures, sound, video, animation, and simulations to represent the learning material is more appealing to many forms of learning (Andresen and Brink, 2013). Some students would gain more from learning by reading, while others would gain more from learning by listening, and so on, in line with the issues discovered during the analyzing process. Then, this became the researcher's incentive to design EVE as supplementary material to support the process of teaching and learning vocabulary.

The researcher named the product as "EVE" and it stands for “English Vocabulary Exercises." For the teaching materials, the researcher created an electronic game that lasted around 50 minutes. The electronic game's 50-minute teaching materials 
were divided into three sections: The product included instructions on how to answer all of the games in the first 5 minutes. Then, in the 30 minutes part of the product the participants will answer or do all the games that contained in the product. For the last 15 minutes, teacher or parents will discuss the answer with the participants. The games would be designed in several types by using Hot Potatoes that allowed the researcher to add pictures and background. As a result, the students will be more motivated to learn the vocabulary.

The media options were the third element. Using multimedia that included pictures and other items. In order to achieve the learning objectives, it was essential to choose the right media. To supplement the learning materials in this study, the researcher decided to create an electronic game with colorful pictures. Because of the software's accessibility, the researcher decided to use it to create the electronic game. The software was "Hot Potatoes". Hot Potatoes were made by the University of Victoria in Canada. Educational institutions around the world have freely used this software. This application was created as a tool to explore questions so that the question display is not monotonous. Hot Potatoes are often referred to as the tool for making a question bank. This is because this application focuses on being a learning medium for making questions. Hot Potatoes consists of six programs that can be used to create interactive web-based teaching materials and questions It may be used in the teaching and learning process to deliver the content This 
software also provides a number of tools for creating a good game, and it may be used in combination with other media to support in the development of the product. The researcher was also able to edit each type of game before combining them all into a single game. In this research, the researcher used internal evaluation. This electronic game's internal evaluation was used to identify its usability. During the implementation phase, the research found that the content is appealing to the students, and they can use it independently. The data was collected through observation and questionnaires during the implementation phase. The implementation's specific goal is to see whether EVE can be used to teach vocabulary to elementary level students. As a result of the implementation to students, some aspects, such as clearer guidance, larger text, and a better background image, need to be revised. Furthermore, the researcher hopes that after revising the product, this product will be more appropriate.

\section{CONCLUSION}

The low participation and enthusiasm of elementary school students during the learning process, their lack of interest, which influences their learning process, and the lack of completed or appealing instructional materials are all problems in learning vocabulary.

Supplementary materials, specifically "EVE," will help solve these issues. Also, EVE as an electronic game, which is developed with the software of chosen and presented according to the students' grades and the teacher's 
criteria for supplementary teaching materials.

The electronic game also uses pictures that are related to the vocabularies to illustrate them. The electronic game was created with vocabularies that were not included in the syllabus. The product was given the name "EVE" by the researcher, which stands for "English Vocabulary Exercises." For the entire vocabulary materials, the electronic game lasted about 50 minutes. EVE as the electronic game is useable to support the teaching of vocabulary for the elementary level students.

\section{REFERENCES}

Amir, E., Siswaningsih, W., \& Hana, M. N. (2013). Pengembangan web assesment dengan hot potatoes pada materi reaksi oksidasi dan reduksi. Jurnal
Riset Dan Praktik Pendidikan

Kimia.

Andina, S. . (2016). Designing

supplementary material to

introduce grammar use for

writing descriptive and recount

text by using comic.

https://repository.usd.ac.id/6795/

Andresen, B. B., \& Brink, K. (2013).

Multimedia in education

curriculum. UNESCO Institute

for Information Technologies in

Education.

Branch, R. (2009). Instructional

Design: The ADDIE approach.

Springer Science+Business

Media.

Braun, V., \& Clarke, V. (2006).

Using thematic analysis in psychology. Qualitative

Research in Psychology, 3, 77101.

Cohen, L., Manion, L., \& Morrison, 
K. (2018). Research methods in education. Routledge.

Forest, E. (2017). ADDIE Model:

Instructional Design.

Frameworks \& Theories.

Khikmawati, M. N. (2014). Perangkat lunak untuk tes berbasis

perangkat elektronik. PPPPTK

Matematika in Artikel, 1-7.

Kiat, T. Y., Jumintono, Kriswanto, E.

S., Sugiri, Handayani, E.,

Anggarini, Y., \& Rofik, M.

(2020). The effectiveness of

multimedia learning on

academic achievement in

reproduction topic science

subject. Universal Journal of

Educational Research, 8(8),

$3625-3629$.

https://doi.org/10.13189/ujer.202

0.080839

Leow, F. T., \& Neo, M. (2014).

Interactive multimedia learning:
Innovating classroom education

in a Malaysian university.

Turkish Online Journal of

Educational Technology, 13(2),

99-110.

Pun, M. (2013). The use of

multimedia technology in

English language teaching: A

global perspective. Crossing the

Border: International Journal of

Interdisciplinary Studies, 1(1),

29-38.

https://doi.org/10.3126/ctbijis.v1

i1.10466

Puspita, A. R., Sada, C., Training, T., \& Faculty, E. (2017).

Vocabulary Development for

Year-7. Jurnal Pendidikan Dan

Pembelajaran Khatulistiwa, 6(3), 1-13.

Reddy, V. P. (2014). The influence of social media on international students' choice of university 
and course. School of

Information Systems Science \&

Engineering Faculty Queensland

University of Technology, 1-

205.

Sutini, C., Emzir, \& Rasyid, Y.

(2021). The Relevance of

Reading Teaching Material

Using New Technology. Journal

of Physics: Conference Series,

1764(1).

https://doi.org/10.1088/1742-

6596/1764/1/012145

Syamsudin, S., \& Kurniawati, L.

(2016). Using Hot Potatoes

Program for Reading Test

Instrument in English Teaching

Learning Process. IJET

(Indonesian Journal of English

Teaching), 5(2), 242-254.

https://doi.org/10.15642/ijet2.20

16.5.2.242-254

Szudarski, P. (2018). What is vocabulary? In Corpus

Linguistics for Vocabulary.

https://doi.org/10.4324/9781315

107769-4

Zhang, Y., \& Wildemuth, B. M.

(2009). Applications of social

research methods to questions in

information and Library Science.

International Journal. 